\title{
GTP-Binding Protein Rheb
}

National Cancer Institute

\section{Source}

National Cancer Institute. GT P-Binding Protein Rheb. NCI Thesaurus. Code C115291.

GT P-binding protein Rheb (184 aa, $20 \mathrm{kDa}$ ) is encoded by the human RHEB gene. This protein plays a role in the positive regulation of MTORC1-mediated signal transduction. 